\title{
Foraminifera and bacterial activity in oil spill impacted mangrove, Guanabara Bay, Brazil
}

\author{
Luiz F. Fontana ${ }^{1}$; Lázaro L. M. Laut ${ }^{1}$; A. G. Figueiredo Jr. ${ }^{1}$; \\ M. A. C. Crapez ${ }^{2} \&$ T. D. L. Rosa $^{2}$ \\ ${ }^{1}$ Departamento de Geologia, LAGEMAR/UFF, Universidade Federal Fluminense, \\ Niterói, RJ, Brazil - Iffontana@igeo.uff.br \\ ${ }^{2}$ Departamento de Biologia, BIOMAR/UFF, Universidade Federal Fluminense, Niterói, RJ, Brazil
}

Studies on the selectivity of foraminiferal feeding have shown that bacteria are an essential food, but can also successful to survive in the absence of these. Absence of bacteria apparently affects foraminiferal reproduction. Foraminifers are known to live in symbiosis with bacteria but some species have been seen surviving in areas of reduced. Despite many studies on the foraminifers-bacteria relationship, the bacteria role on foraminiferal life cycle is still partially unknown.

The present work has the objective of evaluating foraminiferal distribution and bacterial enzymatic activity as environmental bioindicators. The study area is located in Suruí River mangrove in the Guanabara Bay, impacted by PAHs. Twenty-three samples were collected for bacterial analyses, including ETSA (electron transport activity system) EST (Sterases), bacterial carbon, bacterial biomass, PAHs (policyclic aromatic hydrcabon), organic matter and foraminifers.

Results of enzymatic activity shows high values of ETSA and EST represents activity of free enzymes acting in larger molecules (600 Da) and thus, facilitating the absorption of these by the bacteria. The analyses of EST had demonstrated higher activity than ETASA thus evidencing the presence of larger molecules. PAHs have high values distributed in all samples; the largest values were of phenantrene ranging from $0.2-0.4 \mathrm{~g} / \mathrm{g}$ (grams per grams) of sediment. The lowest values were of benzo(a)pyrene varying from 0 to 0.000005 $\mathrm{g} / \mathrm{g}$ of sediment. Organic matter varied from 0.02 to $0.59 \mathrm{~g} / \mathrm{g}$ of sediment and

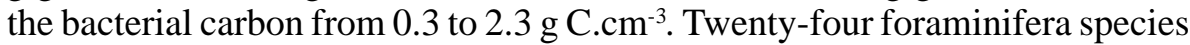
were identified in Surui's mangrove with dominance of $A$. mexicana and $H$. wilberti in all samples and $T$. inflata and T. macrescens only in the interior regions.

A multivariate analysis in CCA was applied to know how PAHs influence foraminiferal species and enzymatic bacteria activity distribution in the mangrove. It was found that benzo(a)pyrene and the phenantrene are the most influencing compounds. The foraminifers' species Ammotium cassis and Ammobaculites 
Foraminifera and bacterial activity in oil spill impacted mangrove, Guanabara Bay, Brazil Luiz F. Fontana; Lázaro L. M. Laut; A. G. Figueiredo Jr.; M. A. C. Crapez \& T. D. L. Rosa

exiguus, as well as EST and bacterial carbon had responded positively to these substances. Species Quinqueloculina laevigata and Saccammina sp. had responded negatively. Trochammina macrescens was the species most neutral to the PAHs.

Enzymatic bacterial activity of EST is directly related the larger molecules, thus our results demonstrate that autochthones bacteria are consuming oil and consequently increasing its biomass. This bacterial activity creates favorable conditions for development of foraminifers in oil spill impacted mangrove. 